\title{
Histologic Test
}

National Cancer Institute

\section{Source}

National Cancer Institute. Histologic Test. NCI Thesaurus. Code C49131.

A diagnostic test used to examine and define microscopic tissue structure, composition,

or etiology. The test results are often used by a clinician to diagnose disease or disordered function. 